\title{
PREFERÊNCIA DA PAISAGEM NO CENTRO DE PANAMBI/RS: ESPAÇOS LIVRES DE LAZER E RECREAÇÃO
}

\author{
LANDSCAPE PREFERENCE IN THE CENTER OF PANAMBI/RS: OPEN SPACES
}

\section{RESUMO}

Praças e parques são espaços livres essenciais para a estruturação e funcionalidade da vida urbana, que buscam promover a sociabilidade, construir uma identidade local, qualidade ambiental e de vida para a população. Deste modo, este trabalho teve como objetivo analisar os espaços livres de lazer e recreação de Panambi/RS, ou seja, as praças/parque, além de avaliá-los por meio da preferência da paisagem, com aplicação de questionários através da percepção e opinião da população, e por fim, contribuir com recomendações que subsidiem a gestão e planejamento territorial de futuras intervenções e manutenção. Considera-se então que a Preferência da Paisagem facilitou o cumprimento dos objetivos estabelecidos e se espera que as recomendações e sugestões ponderadas nas áreas de recreação e lazer do bairro Centro de Panambi sejam considerados pela gestão pública, para que cumpram a sua função na cidade e mantenham equilíbrio no meio urbano, com conforto e qualidade para os cidadãos.

Palavras-chave: Preferência da Paisagem. Questionários. Praça. Parque urbano.

\section{ABSTRACT}

Squares and parks are open spaces essential for the structuring and functionality of urban life, which seek to promote sociability, build a local identity, environmental quality and life for the population. Thus, this research had as objective to analyze the leisure and recreation spaces of Panambi/RS, that is, squares/park, as well as evaluating them through landscape preference, applying questionnaires through the perception and opinion of the population, and finally, contributing with recommendations that subsidize the management and territorial planning of future interventions and maintenance. It is considered that the Landscape Preference facilitated the achievement of the established objectives and it is expected that the recommendations and suggestions weighted in the recreation and leisure areas of the Panambi downtown neighborhood will be considered by the public management, so that they fulfill their function in the city and maintain balance in the urban environment, with comfort and quality for the citizens.

Keywords: Landscape Preference. Questionnaires. Square. Urban park.

\section{Samara Simon Christmann ${ }^{\text {a }}$} (D) Eliane Maria Foleto ${ }^{b}$

${ }^{a}$ Universidade Federal de Santa Maria (UFSM), Santa Maria, RS, Brasil

DOI: $10.12957 /$ geouerj.2020.33420

Correpondência: samara.s.c@hotmail.com

Recebido em: 2 abr. 2018

Revisado em: 3 maio 2019

Aceito em: $8 \mathrm{fev} .2020$ 


\section{INTRODUÇÃO}

Praças e parques são espaços livres essenciais para a estruturação e funcionalidade da vida urbana. Estes ambientes constituem-se paisagem e unidades urbanísticas, que buscam promover a sociabilidade (encontro, circulação, permanência, descanso), apreciação cênica, seu uso e conservação, exaltar potenciais ambientais, construir uma identidade local, contato com áreas verdes, qualidade ambiental e de vida para a população. Neste sentido, os cidadãos possuem direitos garantidos por lei de terem acesso com qualidade ao lazer.

Desde a Antiguidade estes espaços livres se manifestaram no desenho, configuração e organização das cidades, mesmo que não com os mesmos usos, conceitos e significados. Por isso, são considerados referenciais históricos, simbólicos, culturais, sociais, ambientais, políticos e cívicos. Devido a toda uma dinâmica, expansão, e às transformações do cenário urbano, eles adquirem valores, formas e funcionalidades, e estão sujeitos à intervenção, manutenção ou conservação dessas paisagens com o propósito de proporcionar benefícios a todos.

Desta forma, espaço livre intraurbano pode ser definido por todas as áreas não contidas por edifícios de moradia e trabalho ou destinado a algum tipo de uso urbano ao ar livre, de caráter público ou privado, e que configura espaços dentro do tecido urbano, como as ruas, pátios, estacionamentos descobertos, jardins, terrenos baldios, largos, praças, parques, rios, lagos, campos, bosques, florestas, vazios urbanos, etc. (MAGNOLI, 1982; MACEDO, 1995; MACEDO; ROBBA, 2002).

Portanto, para esta pesquisa ressaltam-se os espaços livres de lazer e recreação, contemplando as praças e os parques, "cujo planejamento visa atender a demanda da comunidade urbana por espaços abertos que possibilitem a recreação, o lazer e a conservação da natureza" (MARTINS, 2014, p. 20), que se tornaram fundamentais na dinâmica urbana, ao permitirem diferentes possibilidades de uso, apreciação, apropriação e entendimento da sua importância (PIPPI et al., 2011).

Logo, ao se ter consciência da importância dos espaços livres de lazer e recreação para os cidadãos e cidades, questionou-se: quais são as características físico-ambientais dos espaços livres do bairro centro de Panambi/RS? Quais são os padrões de uso/atividades, apropriação e interação? Qual a importância dessas paisagens e qual a percepção da população? Quais as necessidades da maior parte dos usuários em termos de lazer e recreação?

Com esse conhecimento sobre os usuários e sua percepção, possibilita-se compreender mais sobre suas relações, usos e a importância destas paisagens para a dinâmica social, histórica, cultural, e ambiental. Fato esse que poderá colaborar para o estabelecimento de diretrizes de planejamento e gestão da paisagem, com 
a finalidade de conservar, manter uma qualidade visual e condicionar os espaços livres de acordo com as necessidades dos usuários, e assim garantir a qualidade de vida urbana aos cidadãos.

Deste modo, este artigo - que integra parte da dissertação "Espaços livres de lazer e recreação de Panambi/RS: da análise e percepção à gestão da paisagem", do Programa de Pós-Graduação em Geografia da UFSM, em nível de mestrado - tem como objetivo analisar os espaços livres de lazer e recreação de Panambi/RS, ou seja, as praças/parque, ao considerar os seus aspectos físico-ambientais (recursos naturais, estruturas físicas, mobiliário urbano e infraestrutura), características, funcionalidades, e formas de uso, além de avaliá-los por meio da preferência da paisagem, através da percepção e opinião da população, e contribuir com diretrizes/recomendações que subsidiem a gestão e planejamento territorial de futuras intervenções e manutenção.

Com isto posto, este estudo se torna relevante, pois promoverá análises com os principais espaços livres da cidade de Panambi - que tem sido bastante modificados, ou estão em desuso pela falta de planejamento e gestão -, além de serem observados a sua qualidade ambiental-paisagística e considerações antrópicas. E, ao se chegar ao fim da pesquisa, pretende-se contribuir com o planejamento territorial das áreas de estudo e apresentar ações e recomendações que podem vir a serem tomadas por parte do poder público.

Portanto, esta pesquisa se delimita em investigações e concepções exploratórias desses espaços livres intraurbanos, e empíricas de percepção da população, com abordagem quali-quantitativa, que proporciona validade aos resultados da pesquisa e informações das características peculiares das áreas de estudo.

\section{PREFERÊNCIA DA PAISAGEM}

A percepção da paisagem se insere com as diferentes perspectivas do estudo ambientecomportamento, principalmente nas áreas de geografia e arquitetura. Neste sentido, os estudos da relação entre o homem e o ambiente, por meio de processos mentais, são denominados de cognição ambiental, em que a percepção é uma dessas etapas (PEREIRA, 2012), e será resultante da associação do ambiente físico com o ambiente percebido (de acordo com as experiências individuais).

Deste modo, a percepção advém desse contato sensorial, com uma ação direta e uma resposta imediata, em relação à preferência, e há uma avaliação do espaço vislumbrado e suas qualidades (KAPLAN, 1985), que pode ser externalizada/transmitida de forma positiva ou negativa. Portanto, a percepção é subjetiva, pois se condiciona a fatores particulares de cada indivíduo, a fatores educativos e culturais, e fatores emotivos, afetivos e sensitivos, derivados das relações do observador com o ambiente (BIONDI, KOZERA, VIEIRA, 2007). No entanto, apesar da subjetividade e individualidade, este tipo de pesquisa possui medidas confiáveis para evidenciar as preferências (ANDRÉ; SCHARZ; SEVEGNANI, 2008). 
Nesta concepção subjetivista, destaca-se a importância para o planejamento ambiental ao se considerar a percepção como um elemento importante de representação social da população sobre seu entorno. Assim, poderá se compreender como a sociedade concebe, percebe e transforma a natureza, por meio das suas atividades, usos, significados e identidade, pois essa imagem mental se reflete no uso e gestão do seu espaço, paisagem e território (VERAS, 1995 apud RODRIGUEZ; SILVA, 2013).

Neste sentido, de acordo com Bernáldez (1985), o estudo da percepção tem uma grande importância, pois permite compreender fenômenos culturais, interpretar o simbolismo no entorno urbano, mas também a reconhecer os recursos naturais e o patrimônio que eles podem representar. Além disso, tais pesquisas são necessárias para atualizar os usos que são atribuídos a uma paisagem, os seus recursos, e principalmente, a propiciar um desenvolvimento equilibrado deles.

Desta forma, sob uma perspectiva empírica e sensorial de valorização da experiência dos indivíduos em relação a uma paisagem, que busca compreender a percepção dos mesmos, destaca-se aqui o estudo da preferência da paisagem. Ele geralmente é um exercício comparativo, com características subjetivas individuais, que leva em consideração a sensibilidade e percepção humana, de ordem estética e psicológica, para compreender as preferências e relações entre uma ou várias paisagens e o homem (BOLÓs, 1992).

Ou seja, conforme Karjalainen (2006) o termo preferência é utilizado no estudo de paisagens, que evidencia o gosto, simpatia e apreciação das pessoas pela paisagem. E além das paisagens refletirem as preferências de seus observadores, evoca os seus sentimentos, tais como acolhimento, tranquilidade, insegurança ou medo (TUAN, 1975).

Kaplan (1985) cita que nesses tipos de pesquisa, existem implicações dos resultados na arquitetura paisagística, tal como o arranjo dos elementos construídos ou naturais no espaço, que é um fator central da preferência humana, e que poderá resultar em alterações da paisagem. Porém, deve haver cuidado para que esse conjunto de conhecimento obtido possa ajudar na tomada de decisões, na gestão e planejamento. Para isso, é necessário considerar respostas da participação pública com as características e opiniões particularmente mais ressaltadas e importantes da paisagem, perguntando quais os seus usos e aspectos positivos e negativos (KAPLAN, 1985).

Portanto, neste trabalho, entende-se que a paisagem resulta das transformações e uso da natureza, sobre a qual se adotam práticas de gestão territorial, e da percepção que o homem estabelece a partir do aproveitamento dos recursos naturais, usos e riscos para suas atividades. Neste sentido, ela só existe na interface sociedade-natureza, ou seja, quando o meio físico/ambiente permite o uso e as dinâmicas de vida das pessoas: habitando, vivendo, compartilhando experiências, e transformando-a pela ação antrópica. 
Assim, para este trabalho, a paisagem configura um espaço livre - as praças ou o parque-, que possuem limites e a ação de gestores sobre a área, com uma natureza implantada e/ou transformada, em que a população usufrui principalmente para o lazer, circulação, recreação ou ainda para a conservação, e que muitos possuem um vínculo de identidade e o veem na representatividade da sua história ou da história local.

Logo, a análise de preferências de uma paisagem pode fornecer parâmetros para a gestão sobre um território, definir prioridades de ação ou conservação, e também subsidiar estratégias de interpretação e sensibilização sobre ele. Por isso, conforme Pereira (2012), a preferência da paisagem se constitui de processos avaliativos afetivos interpretativos e valorativos, que são de suma importância para a avaliação ambiental.

Para Santiago (2009), há uma estreita relação entre o desenho do espaço urbano construído e do não construído, a percepção da paisagem e a qualidade ambiental, a formação de uma imagem da cidade, da composição paisagística, identificação simbólica, e de apropriação dos espaços públicos, com a sua definição. Por isso, os espaços livres, como elementos de integração da vida urbana necessitam de valorização e qualificação.

Assim, a etapa da presente pesquisa sobre a percepção se embasará em uma avaliação através do público em geral associado a fotografias, somadas às questões de uso, qualidades e opiniões referentes aos espaços livres. Este buscará informações da relação entre a paisagem e o homem, as condições atuais do espaço livre e as expectativas futuras.

\section{O MUNICÍPIO DE PANAMBI/RS}

O município de Panambi se localiza na mesorregião Noroeste Rio-Grandense (Figura 1), e sua formação deu-se a partir do final do século XIX e do início do século XX por meio dos fluxos migratórios, com a colonização predominantemente de origem alemã. Com instalação oficial decretada em 1955, possui 38.058 habitantes (conforme o Censo Demográfico do IBGE, 2010), sendo que 90,81\% de sua população está concentrada na zona urbana. Além disso, o município se desenvolve na área educacional e expressivamente na área industrial, sendo um dos principais polos metal mecânicos do Rio Grande do Sul.

Em relação ao seu traçado urbano, destaca-se que se desenvolveu conforme a topografia da cidade, caracterizada por morros e vales, em uma linearidade no sentido norte-sul, com vasta visualização de vegetação (uma característica marcante e representativa em Panambi, tanto em espaços livres públicos como privados). Cortando o traçado urbano há vários arroios e o Rio Fiúza que permeiam também duas das áreas de estudo: o parque urbano, e a Praça do Imigrante. Portanto, possuem em seu território área de mata nativa - de APP (Área de Preservação Permanente). 
Figura 1. Localização do município de Panambi/RS. Fonte: Elaborado pela autora na plataforma ArcGIS, 2016.
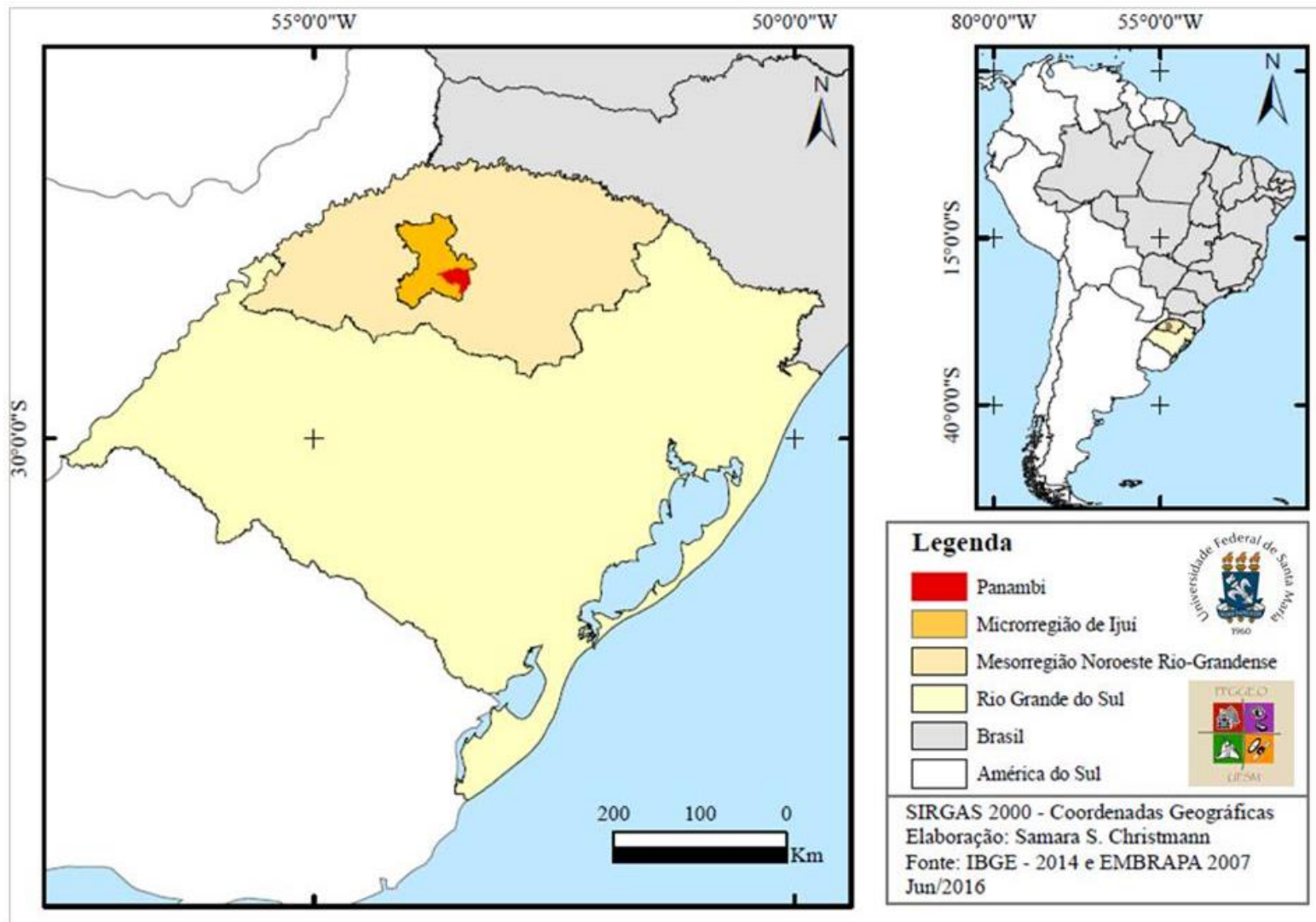

Com isso em vista, elaborou-se na Figura 2 a demarcação no bairro Centro de Panambi/RS dos cinco espaços livres que compõem a pesquisa: o Parque Municipal Rudolfo Arno Goldhadrt; e as quatro áreas nomeadas Praça- Praça Engo Walter Faulhaber, Praça Hermann Steiger, Praça da Emancipação e Praça do Imigrante. Acrescenta-se que se privilegiaram neste estudo apenas esses espaços públicos do bairro Centro visto que possuem regulamento de lei atribuído como parque ou praça, embora nem todos estejam demarcados pelo Plano Diretor de Panambi (2008).

Acerca do bairro Centro, salienta-se que este é o quarto bairro mais populoso (entre os vinte e sete bairros existentes - lei de delimitação criada em 1986) de Panambi (IBGE, 2010), com 2.847 habitantes, o que representa 8,24 \% da população na zona urbana. Núcleo de expansão central, de intensificação da população e das atividades, enfatiza-se que este bairro tem caráter predominantemente comercial, de serviços e residencial. É uma área turística com destaque para o Parque Municipal Rudolfo Arno Goldhardt (incluindo o Museu), o Rio Fiúza, a Praça Engo Walter Faulhaber, alguns templos religiosos (denominação católica, batista e luterana), e dois bens culturais tombados pelo município: o Edificío Rudi Arnoldo Franke e o Castelinho, e o Monumento ao Imigrante da Praça do Imigrante. 
Figura 2. Localização dos espaços livres de lazer e recreação do bairro Centro de Panambi. Fonte: Adaptado do Mapa Urbano do Plano Diretor de Panambi - RS (2008).

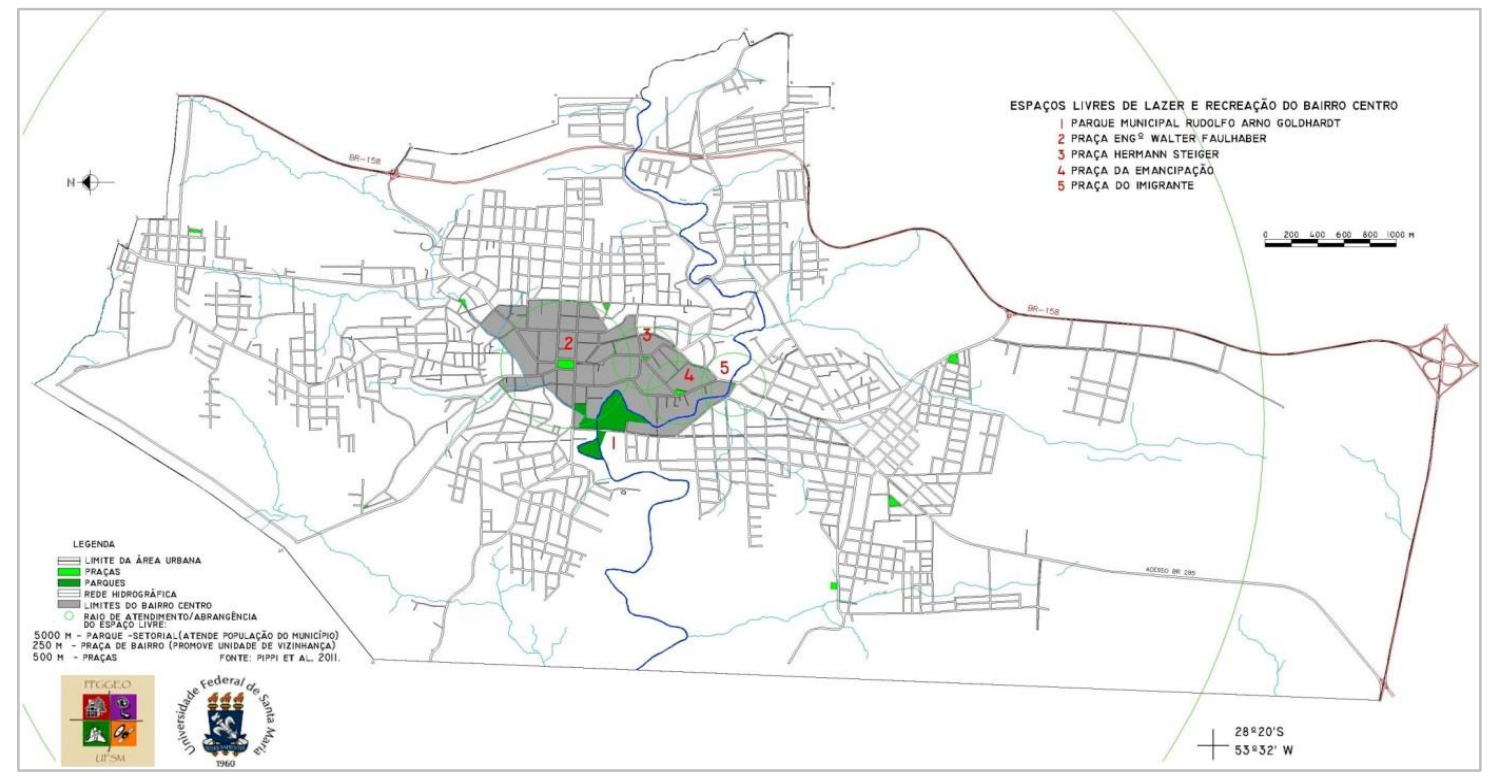

Logo, com todas essas informações sobre o município e área de estudo, parte-se para a metodologia, a caracterização das paisagens em estudo (as quatro praças e o parque) e os resultados advindos da aplicação da pesquisa.

\section{PROCEDIMENTOS METODOLÓGICOS}

Evidencia-se que não há um método ou modelo único que determine a forma de avaliar a percepção das áreas públicas de lazer e recreação, visto que cada uma das paisagens, bem como em cada município as realidades e características são diferentes. Porém, seguiu-se o mesmo protocolo de aplicação em todos os espaços livres, que consistiu na análise dos espaços livres (observação direta da pesquisadora), e na Preferência da Paisagem, com aplicação de questionários (ANEXO A) a 261 respondentes. Esse questionário contempla uma amostragem não probabilística ${ }^{1}$ de pessoas residentes em Panambi, que ao menos frequentou uma vez um dos espaços livres no último ano.

Portanto, este trabalho se baseou em três etapas. A etapa inicial, de análise do espaço livre buscou registrar os tipos de conectividades e acessibilidade, condicionantes físico-ambientais, infraestrutura, recursos ambientais e construídos, relação com o entorno imediato, composição paisagística, funcionalidades, tipos de uso e atividades no Parque Municipal. Para isso, foram realizadas pesquisas históricas no Museu de Panambi

\footnotetext{
${ }^{1}$ A amostragem não probabilística não apresenta fundamentação matemática ou estatística, e depende de critérios do pesquisador. Foi adotada a do tipo intencional, que consiste em selecionar um subgrupo da população que, com base nas informações disponíveis, possa ser considerado representativo de toda a população. (GIL, 2008).
} 
(MAHP) e um levantamento de campo, interpretada em observação direta pela pesquisadora, com base em uma pesquisa qualitativa de caracterização dos espaços livres desenvolvida e por Pippi et al. (2011).

Em seguida submeteu-se o trabalho à preferência da paisagem, que liga os aspectos empíricos e sensoriais, e quali-quantitativo no questionário. A abordagem qualitativa inclui as respostas de atribuições subjetivas de significado às paisagens, e a quantitativa abrange a mensuração dos fenômenos, com a coleta de dados numéricos e o uso da técnica estatística de média simples e porcentagem, e por fim, o tratamento por meio da interpretação visual em tabelas e gráficos.

Logo, o estudo da preferência da paisagem nos espaços livres do bairro Centro de Panambi/RS se embasou na coleta de dados a campo e com o uso de fotografias, em que foi determinada valoração pelos observadores, através da visualização de substitutos da paisagem (imagens que simulam o ambiente real).

Tendo-se isso em vista, foram registradas inúmeras fotografias diurnas, que consistiram um fototeste de imagens que simulam o ambiente real (PEREIRA, 2012) -, nas mais diversas possibilidades e perspectivas para cada categoria de paisagem. Salienta-se que elas foram sempre obtidas nos mesmos horários e com condições climáticas (céu limpo) semelhantes: para o Parque, nos dias 03/11 e 07/11/2017, das 09h às 12h; e todas as praças, no dia 10/10/2017, entre às $09 \mathrm{~h}$ e $12 \mathrm{~h}$.

Destas, foram selecionadas fotografias com perspectivas diferenciadas cujas vistas possibilitassem uma boa representatividade da área de cada categoria, e, que contemplasse essa categoria em atividades, estruturas, setores e usos do parque. Dentre todas elas, elegeu-se também subcaterigorias (por haver diferentes ambientes com a temática da mesma categoria), e, para cada categoria estabelecida (ou subcategoria, se houvesse) foi escolhida apenas uma foto (com padrão de cores, legibilidade, e uma bacia visual relevante para a categoria).

Deste modo, devido à diversidade de atividades no Parque, registrou-se 241 fotografias, as quais foram subdivididas em dez categorias: acesso; edificações principais (2 subcategorias: ginásio; e salão de eventos); áreas esportivas (4 subcategorias: área central de esporte e recreação; gramado esportivo; área de exercícios e campos esportivos; e a pista de skate); anfiteatro; playground; academia ao ar livre; Casa das Etnias; trilhas; espaço gourmet; rio Fiúza (que interliga as áreas do parque).

Na Praça Engo Walter Faulhaber registraram-se 172 fotografias, as quais foram subdivididas em sete categorias: área sul da praça (2 subcategorias: vista principal; e Palanque Oficial/área aberta); monumentos (2 subcategorias: Monumento à Bíblia e Portal das Colonizações); playground; banheiros; edificação estilo germânico (Kaufhaus); paisagismo (3 subcategorias: caminhos; vista para vegetação; e canteiro central); e área com pergolados. 
As demais praças (Hermann Steiger - 27 fotografias; Emancipação - 30 fotografias; e Imigrante - 28 fotografias), devido às menores dimensões e poucas atividades, padronizou-se em três categorias, o que contemplou vistas, acessos ou caminhos internos/externos, playground (na Praça da Emancipação) e monumento (na Praça do Imigrante). Todas as fotografias poderão ser visualizadas adiante nos resultados da pesquisa.

Para os registros fotográficos utilizou-se uma câmera Kodak de 14 megapixels, e a sua impressão, para manusear com os entrevistados, possuía qualidade em papel foto, em tamanho $10 \times 15 \mathrm{~cm}$, julgado como mais adequado para o manuseio, juntamente com os questionários de Preferência da Paisagem (ANEXO A).

Portanto, para que os observadores atribuíssem a sua valoração para cada fotografia, elaborou-se uma classificação (Figura 3), para a percepção de cada cidadão questionado, em Classes de 1 a 5 para as fotografias da paisagem.

Figura 3. Classes de Preferência da Paisagem. Fonte: Elaborado pela autora, com base em Kaplan (1985), Marenzi (1996) e Pereira (2012).

$\begin{array}{cc}\text { Classe 5 } & \text { Preferência Muito Alta } \\ \text { Classe } 4 & \text { Preferência Alta } \\ \text { Classe } 3 & \text { Preferência Média } \\ \text { Classe 2 } & \text { Preferência Baixa } \\ \text { Classe } 1 & \text { Preferência Muito Baixa }\end{array}$

Associado ao estudo perceptivo da preferência da paisagem houve uma continuação do questionário (ANEXO A), que solicitou informações sobre o perfil do usuário entrevistado, e outras questões para apreender a opinião particular sobre a paisagem em questão. Esse questionário foi organizado a partir de trabalhos já realizados com metodologias quantitativas e qualitativas, de interação com os usuários, de análise de espaços livres intraurbanos públicos, pelo Grupo de Pesquisa Quapá-SEL do Núcleo Santa Maria, do laboratório PARQ - Paisagismo e Arquitetura do curso de Arquitetura e Urbanismo da UFSM (PIPPI et. al, 2015). Grupo este que visa dialogar com a rede nacional de pesquisa do Laboratório da Paisagem (LabParc) da Faculdade de Arquitetura e Urbanismo da Universidade de São Paulo (FAU-USP), que propõem a criação de núcleos regionais de pesquisa por todo o Brasil sobre as discussões do paisagismo e espaços livres.

Conforme Pippi et al. (2015), o objetivo de tal aplicação de interação com os usuários com abordagem do tipo quali-quantitativa, com perguntas abertas e fechadas, concebe o registro das informações de quem são os entrevistados; se estes utilizam os ambientes dos espaços livres e como se relacionam com suas paisagens; quais são as atividades desenvolvidas; e como as características físico-ambientais afetam o uso e apropriação do espaço. Portanto, a aplicação desse instrumento seguiu a anotação de variáveis sociais (perfil dos usuários, frequência de uso, tipo de uso/atividade, relação com o espaço). 
A etapa qualitativa do instrumento consistiu em perguntas abertas que contribuíram com a compreensão de tópicos como: "motivações, emoções, percepções, aspectos positivos, aspectos negativos, atividades/padrões de uso e ambientes preferenciais" e sugestões para a paisagem (PIPPI et al., 2015, p. 152). Ali, as questões foram abordadas com o objetivo de averiguar a satisfação, desejos, vínculos e identidade com o espaço livre. E a parte quantitativa consistiu em perguntas fechadas com questões de múltipla escolha e linguagem simplificada, que coletou informações como do tipo de atividades e uso, intensidade e frequência do uso na paisagem, além de informações do perfil dos entrevistados.

Assim, para esta pesquisa, adotou-se que para cada categoria de fotografias estipuladas de um espaço livre, haveria 10 questionários de amostra, o que resultou em: Parque Municipal Rudolfo Arno Goldhardt - 10 categorias, portanto 100 questionários; Praça Engo Walter Faulhaber - 7 categorias, 70 questionários; Praça Hermann Steiger, Praça da Emancipação e Praça do Imigrante: 3 categorias, 30 questionários para cada.

Deste modo, a coleta dos dados foi aplicada praticamente em cidadãos que estivessem em outros locais (que não a paisagem em estudo), como instituições, comércios, residências e serviços do entorno, mas que utilizassem a paisagem referida ao menos uma vez ao ano. Isso tudo totalizou 260 questionários para a aplicação: no mês de outubro e início de novembro de 2017 para as quatro praças (160 questionários); e no restante do mês até metade de dezembro de 2017, para completar a coleta necessária do parque (100 questionários). Porém, ao final, obteve-se 261 questionários respondidos.

Em relação ao perfil dos entrevistados (ANEXO A) salienta-se que houve um cuidado na coleta em igualdade nas categorias de gênero (feminino/masculino) e entre três faixas etárias estipuladas (até 17 anos; entre 18 e 44 anos; e acima de 45 anos). Houve também na ficha a solicitação para preenchimento, o nível de escolaridade.

Com esses dados coletados, a pesquisa prosseguiu com a sua análise: leitura dos questionários; organização, categorização e tabulação dos dados; tratamento, análise e redação dos dados obtidos. Desta forma, foi elaborada uma matriz de dados em uma planilha eletrônica do Excel, o que permitiu a sistematização de informações por categorias do questionário e posteriormente a elaboração de gráficos, tabelas e sua descrição, para o estabelecimento dos resultados e discussões de cada paisagem, e uma possível relação ou convergência entre elas. Portanto, no processo de tratamento e análise dos dados houve testes de médias simples efetuadas de cada fotografia (pela Classe de Preferência), e testes de porcentagens/médias comparativas nas demais questões sociais ou sobre a paisagem.

Através da análise das evidências de maiores e menores porcentagens e médias simples registradas em gráficos e tabelas, objetivou-se com esse procedimento conhecer a preferência pelos ambientes/lugares da paisagem dos espaços livres (quais ambientes são os mais ou menos preferidos/agradáveis/usuais), quais as 
atividades mais desempenhadas ou preferíveis no espaço livre, e quais as considerações/adaptações ou melhorias necessárias/opiniões sobre as categorias de paisagem do espaço livre, ou a paisagem em si.

Por fim, a última etapa do trabalho consistiu em contribuir com medidas que subsidiassem a gestão e planejamento territorial de futuras intervenções e manutenção dos espaços livres. Consideraram-se seus conflitos e fragilidades, e as potencialidades para investimento, por meio de recomendações para cada uma das paisagens, com base na análise e coleta de dados com os entrevistados.

\section{ESPAÇOS LIVRES DE LAZER E RECREAÇÃO DE PANAMBI/RS}

Ao se considerar a grande quantidade de dados coletados e os diversos gráficos e tabelas geradas, optou-se por apresentar as principais/relevantes informações e características dos espaços livres em uma tabela síntese, com os dados obtidos por meio dos questionários na preferência da paisagem, relação de uso com os cidadãos entrevistados e ao final da Tabela 1 as potencialidades de cada área e a contribuição para o planejamento territorial dos espaços livres.

Tabela 1. Síntese dos espaços livres do Centro de Panambi/RS. Fonte: Elaborado pela autora, 2018.

\begin{tabular}{|c|c|c|c|c|c|}
\hline Espaço livre & Parque Municipal & $\begin{array}{c}\text { Praça Engo Walter } \\
\text { Faulhaber }\end{array}$ & $\begin{array}{c}\text { Praça Hermann } \\
\text { Steiger }\end{array}$ & $\begin{array}{c}\text { Praça da } \\
\text { Emancipação }\end{array}$ & $\begin{array}{l}\text { Praça do } \\
\text { Imigrante }\end{array}$ \\
\hline $\begin{array}{c}\text { Principais } \\
\text { característi-cas }\end{array}$ & $\begin{array}{l}\text { Parque urbano de } \\
\text { aprox. } 9 \text { ha., } \\
\text { estruturado por várias } \\
\text { áreas que são } \\
\text { margeadas pelo rio } \\
\text { Fiúza ou afluente. } \\
\text { Paisagem de } \\
\text { relevância ambiental, } \\
\text { infraestrutura verde, } \\
\text { estética, conservação } \\
\text { de recursos naturais, } \\
\text { lazer/recreação/ } \\
\text { esportes, cultura, } \\
\text { circulação e potencial } \\
\text { para educação }\end{array}$ & $\begin{array}{c}\text { Ponto central da } \\
\text { evolução urbanística } \\
\text { do séc. XX, com área } \\
\text { territorial de aprox.. } \\
7.500 \mathrm{~m}^{2} \text {. } \\
\text { Inclui lazer e } \\
\text { recreação, } \\
\text { circulação, } \\
\text { contemplação, } \\
\text { eventos, serviços e } \\
\text { comércio. Possui } \\
\text { potencial } \\
\text { educacional e } \\
\text { patrimonial }\end{array}$ & $\begin{array}{l}\text { Conhecida como } \\
\text { "pracinha do CEP”, } \\
\text { tem em sua forma } \\
\text { um triângulo, de } \\
\text { caract. rotatória } \\
\text { de área residual de } \\
\text { aprox. } 350,00 \text { m²}^{2} \\
\text { Inclui vegetação } \\
\text { de médio e grande } \\
\text { porte e pouco } \\
\text { mobiliário urbano }\end{array}$ & $\begin{array}{l}\text { Triângulo com } \\
\text { maciço arbóreo e } \\
\text { playground, de } \\
\text { baixa qualidade } \\
\text { cênica e } \\
\text { mobiliário } \\
\text { insuficiente } \\
\text { Esta paisagem } \\
\text { atrai } \\
\text { principalmente } \\
\text { moradores do } \\
\text { bairro,jovens e } \\
\text { famílias (com } \\
\text { crianças) }\end{array}$ & $\begin{array}{l}\text { APP à margem } \\
\text { do Rio Fiúza, } \\
\text { em esquina de } \\
\text { fluxo intenso } \\
\text { de veículos. } \\
\text { Local com } \\
\text { vegetação, } \\
\text { Monumento } \\
\text { ao Imigrante e } \\
\text { circulação } \\
\text { breve de } \\
\text { pessoas }\end{array}$ \\
\hline $\begin{array}{c}\text { Questionários } \\
\text { aplicados; } \\
\text { Perfil }\end{array}$ & $\begin{array}{c}100 \text { (49= masculino; } \\
51=\text { feminino); } \\
\text { Média idade: } 33,17 \\
\text { anos } \\
\text { Prevalece escolaridade } \\
\text { ensino fundamental }\end{array}$ & $\begin{array}{l}72 \text { (36= masculino; } \\
\text { 36= feminino); } \\
\text { Média: 33,91 anos; } \\
\text { Prevalece ensino } \\
\text { fundamental }\end{array}$ & $\begin{array}{l}30 \text { (15= masculino; } \\
\text { 15= feminino); } \\
\text { Média: } 31,67 \text { anos; } \\
\text { Prevalece ensino } \\
\text { fundamental }\end{array}$ & $\begin{array}{c}29(14= \\
\text { masculino; } \\
\text { 15= feminino); } \\
\text { Média: } 32,06 \\
\text { anos; } \\
\text { Prevalece ensino } \\
\text { fundamental }\end{array}$ & $\begin{array}{l}30 \text { (15= masc.; } \\
15=\text { feminino); } \\
\text { Média: } 33,23 a \\
\text { Prevalece ens. } \\
\text { fundamental }\end{array}$ \\
\hline $\begin{array}{c}\text { Maiores } \\
\text { frequências de } \\
\text { uso }\end{array}$ & $\begin{array}{l}\text { 1-3x por semana; finais } \\
\text { de semana; com } \\
\text { família, amigos, } \\
\text { crianças e sozinhos; } \\
\text { das } 17-20 \mathrm{~h} \text {; de } 1-2 \mathrm{~h}\end{array}$ & $\begin{array}{c}\text { 1-3x por mês; finais } \\
\text { e dias da semana; } \\
\text { com família, amigos } \\
\text { e sozinhos; das 12- } \\
\text { 16h; em menos de } \\
10 \text { min. }\end{array}$ & $\begin{array}{l}\text { 1-3x por mês; dias } \\
\text { de semana; uso } \\
\text { sozinho, com } \\
\text { amigos e família; } \\
\text { das } 17-20 \mathrm{~h} \text {; em } \\
\text { menos de } 10 \mathrm{~min} .\end{array}$ & $\begin{array}{l}\text { 1-3x por mês; } \\
\text { dias da semana; } \\
\text { com amigos, } \\
\text { sozinhos e } \\
\text { família; das 17- } \\
\text { 20h; em menos } \\
\text { de } 10 \text { min. }\end{array}$ & $\begin{array}{c}\text { 1-3x por } \\
\text { semana; dias } \\
\text { de semana; } \\
\text { sozinhos; das } \\
\text { 12-20h; } \\
\text { menos de } 10 \\
\text { min. }\end{array}$ \\
\hline
\end{tabular}




\begin{tabular}{|c|c|c|c|c|c|}
\hline Espaço livre & Parque Municipal & $\begin{array}{c}\text { Praça Engo Walter } \\
\text { Faulhaber }\end{array}$ & $\begin{array}{c}\text { Praça Hermann } \\
\text { Steiger }\end{array}$ & $\begin{array}{c}\text { Praça da } \\
\text { Emancipação }\end{array}$ & $\begin{array}{l}\text { Praça do } \\
\text { Imigrante }\end{array}$ \\
\hline $\begin{array}{c}\text { Atividades } \\
\text { mais realizadas }\end{array}$ & $\begin{array}{l}\text { Contato com natureza, } \\
\text { observações, interação } \\
\text { social, eventos, } \\
\text { exercícios, e refeições }\end{array}$ & $\begin{array}{c}\text { Observações, } \\
\text { circulação, contato } \\
\text { com natureza, } \\
\text { convívio/interação; } \\
\text { eventos }\end{array}$ & $\begin{array}{c}\text { Circulação, } \\
\text { observações, } \\
\text { contato com } \\
\text { natureza, } \\
\text { interação social, e } \\
\text { curtição }\end{array}$ & $\begin{array}{l}\text { Observações. } \\
\text { contato com } \\
\text { natureza, } \\
\text { circulação, e } \\
\text { interação social }\end{array}$ & $\begin{array}{c}\text { Circulação } \\
\text { observações, } \\
\text { contato com } \\
\text { natureza, e } \\
\text { percurso de } \\
\text { atividades }\end{array}$ \\
\hline $\begin{array}{l}\text { Índice geral da } \\
\text { Preferência da } \\
\text { Paisagem } \\
\text { (fotos) }\end{array}$ & $\begin{array}{c}\mathbf{3 , 6 3} \\
(3,50=\text { masculino }) \\
(3,74=\text { feminino })\end{array}$ & $\begin{array}{c}\mathbf{3 , 4 5} \\
(3,42=\text { masculino }) \\
(3,47=\text { feminino })\end{array}$ & $\begin{array}{c}\mathbf{3 , 5 1} \\
(3,45=\text { masculino }) \\
(3,57=\text { feminino })\end{array}$ & $\begin{array}{c}3,55 \\
(3,41= \\
\text { masculino }) \\
(3,67=\text { feminino })\end{array}$ & $\begin{array}{c}\text { 3,36 } \\
(3,29=\text { masc. }) \\
(3,43=\text { fem. })\end{array}$ \\
\hline $\begin{array}{c}3 \text { paisagens de } \\
\text { maior } \\
\text { preferência }\end{array}$ & $\begin{array}{c}\text { Área central de } \\
\text { esporte e recreação; } \\
\text { gramado esportivo; } \\
\text { trilha }\end{array}$ & $\begin{array}{l}\text { Edificações estilo } \\
\text { alemão; } \\
\text { monumentos; } \\
\text { canteiro florido }\end{array}$ & $\begin{array}{l}\text { Vistas principais; } \\
\text { áreas com bancos }\end{array}$ & $\begin{array}{l}\text { Área interna; } \\
\text { vista principal; } \\
\text { vegetação }\end{array}$ & $\begin{array}{l}\text { Caminho int.; } \\
\text { vista principal; } \\
\text { monumento }\end{array}$ \\
\hline $\begin{array}{l}3 \text { paisagens } \\
\text { mais } \\
\text { representa- } \\
\text { tivas }\end{array}$ & $\begin{array}{l}\text { Área central de } \\
\text { esporte e recreação; } \\
\text { trilha; ginásio }\end{array}$ & $\begin{array}{c}\text { Edificações estilo } \\
\text { alemão; } \\
\text { monumentos }\end{array}$ & $\begin{array}{l}\text { Vistas principais; } \\
\text { área interna }\end{array}$ & $\begin{array}{l}\text { Área interna; } \\
\text { playground; vista } \\
\text { principal }\end{array}$ & $\begin{array}{l}\text { Monumento; } \\
\text { vista principal; } \\
\text { caminho int. }\end{array}$ \\
\hline $\begin{array}{l}\text { Satisfação em } \\
\text { relação à } \\
\text { qualidade da } \\
\text { área e da } \\
\text { gestão }\end{array}$ & Média-alta & Média-baixa & Média-baixa & Baixa-média & Baixa-média \\
\hline $\begin{array}{l}\text { Palavras-chave } \\
\text { principais }\end{array}$ & $\begin{array}{l}\text { Natureza; acolhedor; } \\
\text { bonito; exercícios; } \\
\text { diversão; } \\
\text { tranquilidade; lazer }\end{array}$ & $\begin{array}{c}\text { Vegetação; bonita; } \\
\text { central; histórica; } \\
\text { interação; relaxante; } \\
\text { agradável }\end{array}$ & $\begin{array}{c}\text { Vegetação; } \\
\text { descanso; bonita; } \\
\text { abandonada; } \\
\text { tranquila; insegura }\end{array}$ & $\begin{array}{l}\text { Vegetação; bem- } \\
\text { estar; bonita; } \\
\text { abandonada; } \\
\text { lazer; tranquila }\end{array}$ & $\begin{array}{l}\text { Vegetação; } \\
\text { bonita; } \\
\text { passagem; } \\
\text { monumento }\end{array}$ \\
\hline $\begin{array}{l}\text { Principais } \\
\text { aspectos } \\
\text { positivos }\end{array}$ & $\begin{array}{c}\text { Natureza; } \\
\text { ativ./exercícios; trilha; } \\
\text { esportes; convívio; } \\
\text { grande; lazer }\end{array}$ & $\begin{array}{l}\text { Vegetação; } \\
\text { Localização; } \\
\text { Monumentos/ } \\
\text { Construções }\end{array}$ & $\begin{array}{c}\text { Vegetação; } \\
\text { sombra; } \\
\text { tranquilidade; } \\
\text { bancos; central }\end{array}$ & $\begin{array}{c}\text { Vegetação; } \\
\text { parquinho; } \\
\text { amizade; sombra; } \\
\text { localização; lazer }\end{array}$ & $\begin{array}{c}\text { Vegetação; } \\
\text { passagem; } \\
\text { monumento; } \\
\text { sombra }\end{array}$ \\
\hline $\begin{array}{l}\text { Principais } \\
\text { aspectos } \\
\text { negativos }\end{array}$ & $\begin{array}{c}\text { Banheiros; } \\
\text { vandalismo; sujeira; } \\
\text { estrutura física } \\
\text { (prédios, playground); } \\
\text { mobiliário urbano }\end{array}$ & $\begin{array}{c}\text { Banheiros; } \\
\text { drogados; sujeira; } \\
\text { calçadas; } \\
\text { manutenção; } \\
\text { playground }\end{array}$ & $\begin{array}{l}\text { Mobiliário urb. } \\
\text { (bancos; lixeira; } \\
\text { ilum.); vandalismo; } \\
\text { frequentadores }\end{array}$ & $\begin{array}{l}\text { Mobiliário urb.; } \\
\text { estrutura física; } \\
\text { pavimentação }\end{array}$ & $\begin{array}{l}\text { Lixo;sujeira; } \\
\text { manutenção; } \\
\text { mobiliário } \\
\text { urb.; drogados }\end{array}$ \\
\hline $\begin{array}{c}\text { Principais } \\
\text { sentimentos } \\
\text { despertados }\end{array}$ & $\begin{array}{c}\text { Bem-estar; } \\
\text { tranquilidade; } \\
\text { felicidade; satisfação }\end{array}$ & $\begin{array}{l}\text { Tranquilidade; } \\
\text { desconforto; } \\
\text { bem-estar; } \\
\text { felicidade }\end{array}$ & $\begin{array}{l}\text { Tranquilidade; } \\
\text { alegria; bem-estar; } \\
\text { insegurança }\end{array}$ & $\begin{array}{l}\text { Tranquilidade; } \\
\text { felicidade; bem- } \\
\text { estar; } \\
\text { desconforto }\end{array}$ & $\begin{array}{c}\text { Bem-estar; } \\
\text { indiferença; } \\
\text { tranquilidade }\end{array}$ \\
\hline $\begin{array}{l}\text { Possibilidade } \\
\text { de atividades } \\
\text { futuras }\end{array}$ & $\begin{array}{l}\text { Espaço gourmet; pista } \\
\text { de ciclismo; acomp. } \\
\text { profissional; ativ. } \\
\text { aventura }\end{array}$ & $\begin{array}{c}\text { Espaço gourmet; } \\
\text { mais eventos; } \\
\text { academia; espaços } \\
\text { para convívio }\end{array}$ & $\begin{array}{l}\text { Espaço gourmet; } \\
\text { academia }\end{array}$ & $\begin{array}{l}\text { Academia ao ar } \\
\text { livre; espaço } \\
\text { gourmet }\end{array}$ & $\begin{array}{l}\text { Espaço de } \\
\text { lazer/convívio; } \\
\text { Histórico; } \\
\text { conservação }\end{array}$ \\
\hline $\begin{array}{c}\text { Principais } \\
\text { aspectos para } \\
\text { investimentos/ } \\
\text { fragilidades }\end{array}$ & $\begin{array}{l}\text { Estrutura física; } \\
\text { mobiliário urbano; } \\
\text { falta de } \\
\text { regulamentação de } \\
\text { uso; manutenção/ } \\
\text { limpeza }\end{array}$ & $\begin{array}{l}\text { Banheiros/ est. } \\
\text { física; manutenção; } \\
\text { pavimentação; } \\
\text { mobiliário urbano; } \\
\text { vegetação }\end{array}$ & $\begin{array}{l}\text { Mobiliário urbano; } \\
\text { paisagismo; } \\
\text { pavimentção; } \\
\text { manutenção/ } \\
\text { limpeza }\end{array}$ & $\begin{array}{l}\text { Mobiliário urb.; } \\
\text { estruturas; } \\
\text { manutenção; } \\
\text { pavimentação; } \\
\text { paisagismo }\end{array}$ & $\begin{array}{l}\text { Mobiliário } \\
\text { urb.; } \\
\text { Manutenção; } \\
\text { Limpeza; } \\
\text { Paisagismo }\end{array}$ \\
\hline $\begin{array}{l}\text { Potencialida- } \\
\text { des }\end{array}$ & $\begin{array}{c}\text { Esportivo, recreativo, } \\
\text { turístico; educativo e } \\
\text { de conservação da } \\
\text { paisagem }\end{array}$ & $\begin{array}{l}\text { Histórico; interação; } \\
\text { circulação; } \\
\text { lazer/recreação; } \\
\text { apreciação }\end{array}$ & $\begin{array}{c}\text { Descanso/lazer } \\
\text { passivo; interação } \\
\text { social }\end{array}$ & $\begin{array}{c}\text { Recreação; } \\
\text { lazer/descanso; } \\
\text { interação social }\end{array}$ & $\begin{array}{l}\text { Área verde; } \\
\text { área de } \\
\text { interação }\end{array}$ \\
\hline $\begin{array}{l}\text { Principais } \\
\text { recomenda- } \\
\text { ções }\end{array}$ & $\begin{array}{l}\text { Pista de ciclismo; área } \\
\text { gourmet; playground; } \\
\text { educação ambiental; } \\
\text { estrutura física e } \\
\text { mobiliário; } \\
\text { manutenção/limpeza }\end{array}$ & $\begin{array}{l}\text { Espaços de convívio; } \\
\text { educação } \\
\text { patrimonial/ } \\
\text { histórica; estrutura } \\
\text { física e mobiliário; } \\
\text { segurança; } \\
\text { paisagismo; } \\
\text { pavimentação; } \\
\text { limpeza/manut. }\end{array}$ & $\begin{array}{l}\text { Mobiliário urbano } \\
\text { (princ.. bancos, } \\
\text { lixeiras, } \\
\text { iluminação); } \\
\text { pavimentação; } \\
\text { recomendações de } \\
\text { uso e } \\
\text { conscientização }\end{array}$ & $\begin{array}{l}\text { Academia; espaço } \\
\text { gourmet; } \\
\text { manutenção do } \\
\text { playground; } \\
\text { mobiliário urbano } \\
\text { (bancos; lixeiras e } \\
\text { iluminação); } \\
\text { paisagismo }\end{array}$ & $\begin{array}{c}2 \text { opções: } \\
\text { 1-área verde; } \\
2 \text { - } \\
\text { manutenção; } \\
\text { paisagismo; } \\
\text { mobiliário } \\
\text { urb.; espaço } \\
\text { de interação; } \\
\text { história }\end{array}$ \\
\hline
\end{tabular}


Relacionado à preferência da paisagem, na sequência têm-se todas as 40 fotografias (Figura 4 e 5) dos espaços livres dispostas em rankings (da direita pra esquerda; de cima para baixo) individuais (cada praça/parque), com a média geral total de valoração que elas obtiveram, e com a disposição das Classes de Preferências (cores conforme a Figura 3). Abaixo de cada foto se encontra a média simples de valoração geral, e as médias diferenciadas entre os gêneros (em cada lado da média geral, distinta por cores). Dentre as 40 fotografias, em quatro foram atribuídas valorações que resultaram na classe de preferência alta. Das demais, trinta e três alcançaram a classe de preferência média, em duas a baixa, e uma, muito baixa.

Assim, dentre as fotos do ranking da Praça Hermann Steiger (Figura 4), nas duas primeiras estão duas vistas da praça, em que a primeira é a vista mais lembrada e caracterizada da paisagem, e a segunda é a vista longitudinal que contém menos mobiliário urbano e mais vegetação. As outras duas na sequência caracterizam as áreas mais utilizadas pelos cidadãos, com pavimentação e bancos, e a última demonstra o local menos utilizado em toda a praça, mais escura, que aparenta manutenção baixa em infraestrutura e vegetação na sua área interna.

Figura 4. Ranking de Preferência da Paisagem. Fonte: Elaborado pela autora, 2018.
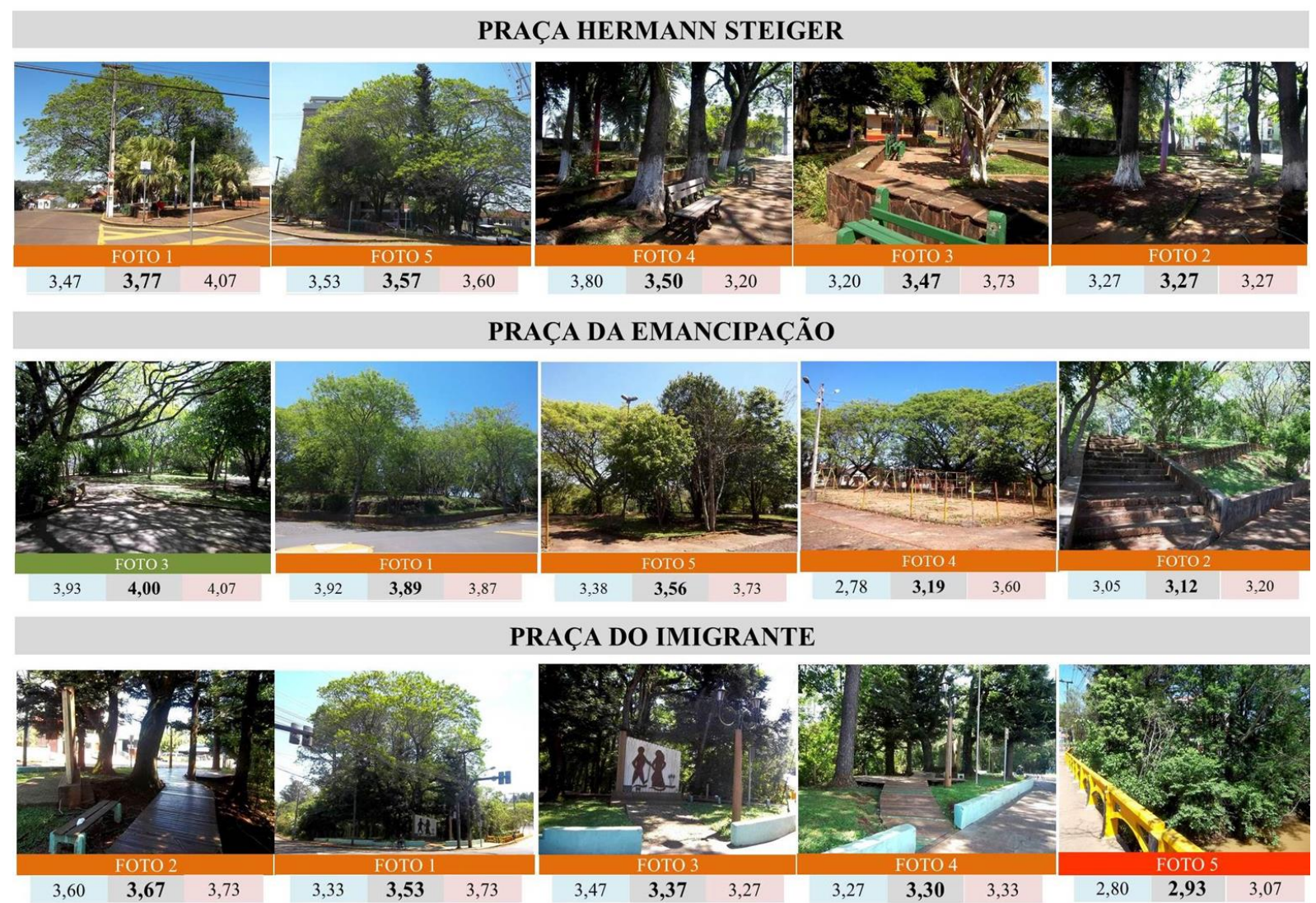

No ranking da Praça da Emancipação (Figura 4), nota-se também que apenas uma fotografia permaneceu na classificação de preferência alta, sendo que esta também é a mais representativa deste espaço 
livre, e concebe a área interna da praça, com predomínio de caminhos e vegetação. Em seguida, dispõem-se as quatro fotografias de preferência média, entre as quais estão: a vista noroeste, com visualização da vegetação, do muro de pedras e rochas expostas; uma vista interna para a vegetação e caminhos; o playground; e um dos acessos por escadas. Destas, há um domínio de vegetação nas duas primeiras, e mais elementos construídos nas duas últimas classificadas.

Dentre as fotos do ranking da Praça do Imigrante (Figura 4), nas duas primeiras estão: uma vista do acesso da praça, e a vista mais conhecida e caracterizada dela, que contém grande cruzamento de veículos e o semáforo (que pode ser visualizado na fotografia também). As outras duas na sequência caracterizam outros dois caminhos, uma que acessa o monumento do Imigrante e a outra com a pavimentação de madeira que conduz à diagonal da praça. E a última fotografia do ranking representa a vista para a praça sobre a ponte do Rio Fiúza, que impede visualização direta para o espaço livre, por conta da vegetação de sua margem.

Já dentre as fotos do ranking do Parque Municipal Rudolfo Arno Goldhardt (Figura 5), a primeira revela a área central de esporte e recreação, local que reúne maior número de usuários em todo o parque, e que é muito utilizado pelas famílias, além de possuir visual estético agradável. Na sequência, as quatro fotografias de preferência média são de áreas esportivas e de exercícios: o gramado esportivo, a trilha, a pista de skate e a academia ao ar livre. $O$ segundo conjunto de preferência média contém fotografias com maior abrangência de edificações, a exemplo do pórtico de acesso, uma academia (da área de exercícios e campos esportivos), o Salão de Eventos e o Ginásio. Em seguida, o terceiro conjunto demonstra fotografias com áreas mais fechadas e sombreadas: o anfiteatro, o espaço gourmet e o playground. Por fim, entre as últimas fotos valoradas do ranking estão o gramado com a Casa das Etnias (em que os entrevistados pouco utilizam, reparam ou vêem sentido de existência) e o Rio Fiúza, que corta as diversas áreas do Parque Municipal (e que foi lembrada a péssima estética causada pelo lixo nas margens, e as pinguelas, que seguidamente estão interrompidas).

No ranking de preferência da Praça Engenheiro Walter Faulhaber (Figura 5), nota-se que as duas fotografias nas primeiras classificações tem uma classe de preferência altas, e ambas contém construções. Na primeira predominam edificações que utilizam em suas fachadas características alemãs (o Kaufhaus e um ponto de táxi), e a segunda o monumento Portal das Colonizações. De acordo com a opinião geral dos entrevistados, estes ambientes são as melhores referências de paisagem para a Praça, apresentam uma iluminação mais adequada, e as melhores condições de manutenção. Em seguida, dispõem-se sete fotografias de preferência média, entre as quais se encontram o canteiro central, o monumento à Bíblia, a vista para o Palanque Oficial, a vista para vegetação, o parquinho, a área com pergolados e passeio, e alguns caminhos internos. Em todas estas, bem como nas de preferência alta, observa-se um equilíbrio entre os elementos construídos/pavimentados e os naturais, tal como a vegetação. Na sequência do ranking tem-se a fotografia número dois, de preferência baixa. Nela podem-se observar a estética da calçada junto ao espaço aberto do 
Palanque Oficial. Tem-se também a fotografia cinco, já na classe de preferência muito baixa, que representa os banheiros públicos da praça, um dos principais motivos de insatisfação das pessoas pela paisagem local.

Figura 5. Ranking de Preferência da Paisagem. Fonte: Elaborado pela autora, 2018.

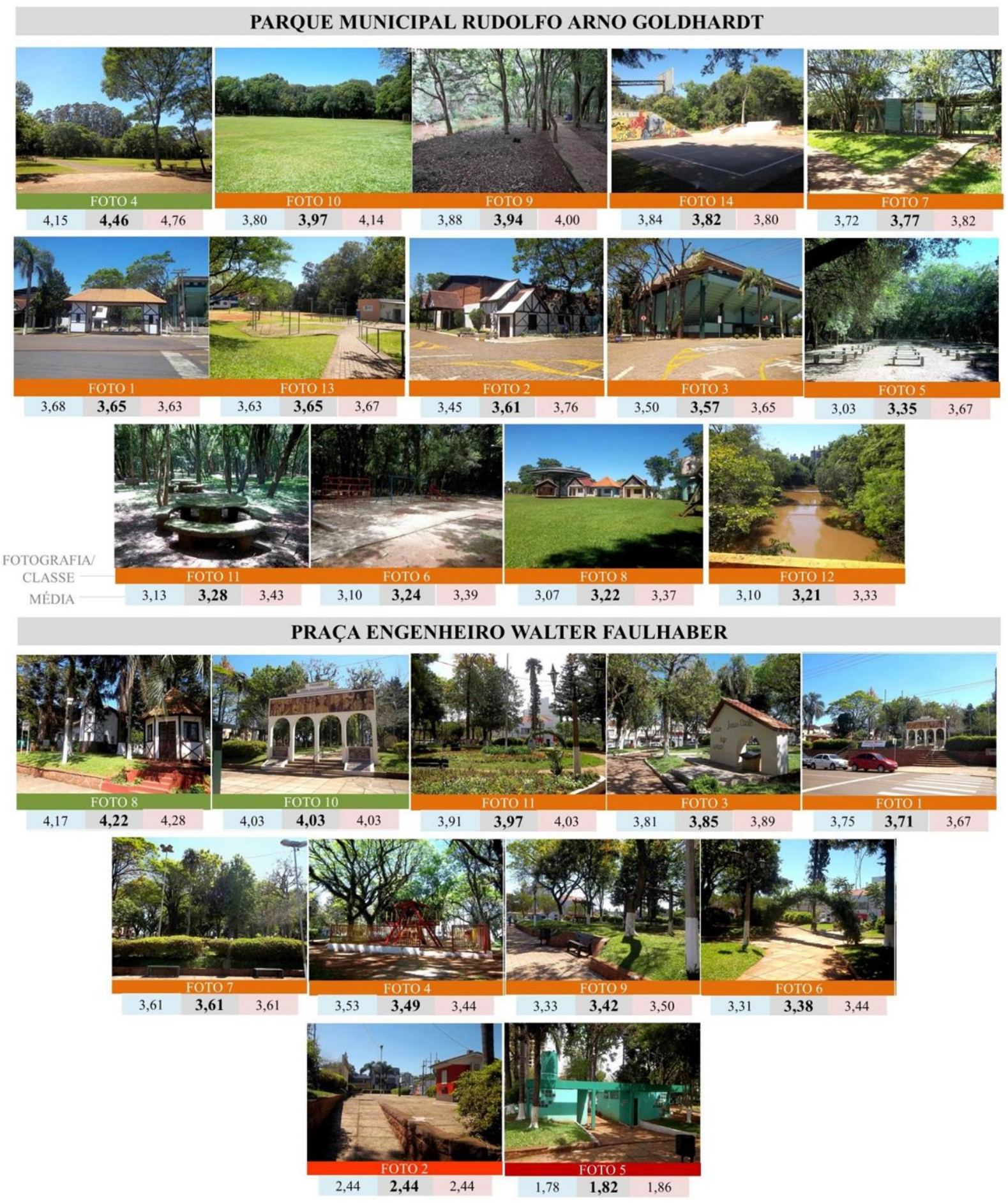

Nesta perspectiva, ao realizar a média simples de todas as fotografias de cada parque ou praça, observou-se que todos os espaços livres receberam a classe de preferência média. 
Na Figura 6 visualizam-se as cinco paisagens com as suas respectivas fotografias que foram eleitas como as mais representativas da área, e no canto esquerdo inferior, destacou-se a valoração geral de cada espaço livre. Evidencia-se que dessas fotografias, quatro foram as mais valoradas de cada parque ou praça (exceto a da Praça do Imigrante).

Figura 6. Fotografias representativas dos espaços livres. Fonte: Elaborado pela autora, 2018.

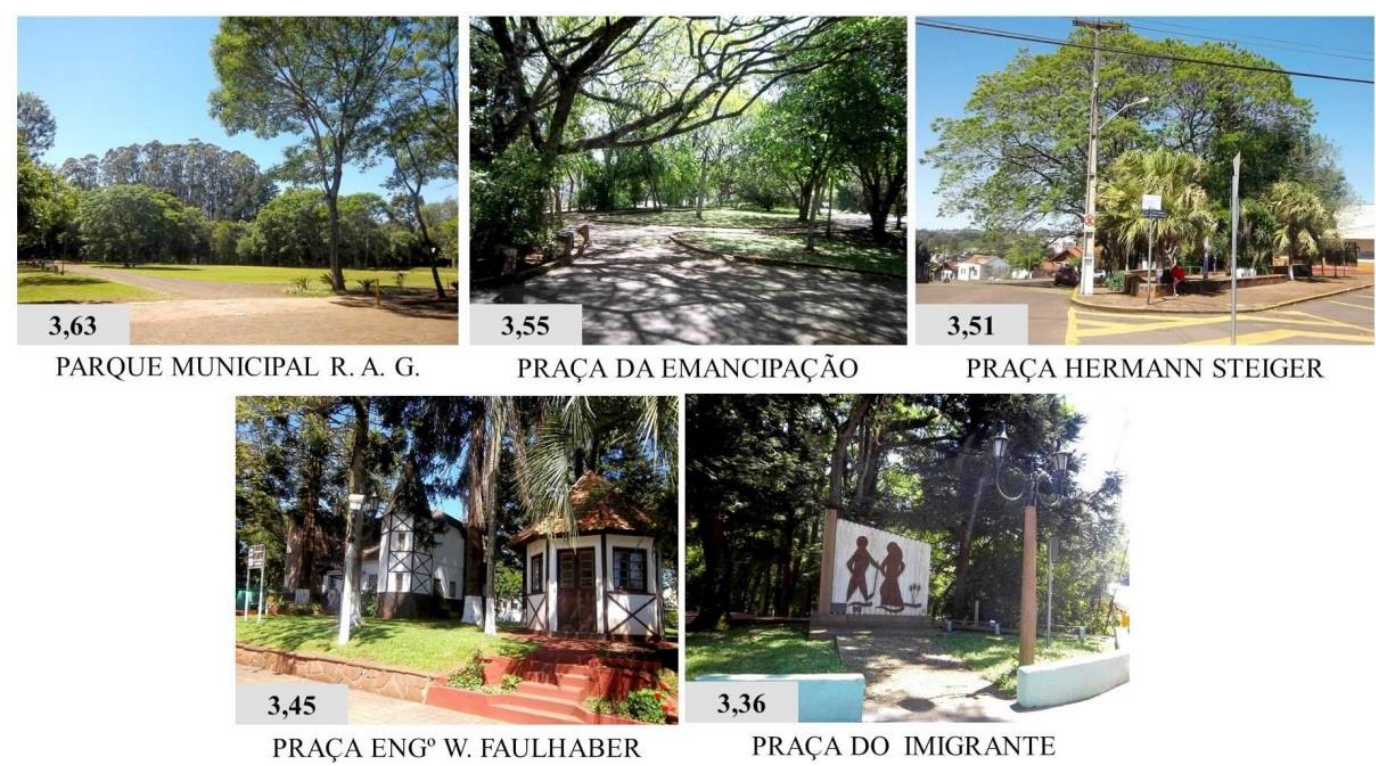

Dentre as áreas, notou-se também que as palavras-chave, aspectos positivos e negativos, e os investimentos induzem as peculiaridades de cada lugar, contudo, mesmo assim, tangem na questão de manutenção, infraestrutura e mobiliário de cada espaço livre.

Logo, na análise de cada paisagem, realizada pela pesquisadora, e na coleta de dados, com as definições de outros vários usuários, constatou-se um diagnóstico semelhante. No entanto, as ações públicas sempre devem estar atentas a essas necessidades da comunidade, e, os espaços livres, serem dinâmicos e se aproveitar desses resultados mais ou menos valorados de cada espaço livre para direcionar o planejamento/estratégias/ações de gestão da paisagem.

\section{CONSIDERAÇÕES FINAIS}

Diante da pesquisa realizada, obteve-se um conjunto de informações sobre as características e importância de existência dos cinco espaços livres de lazer, integrantes de um sistema de espaços livres do bairro Centro de Panambi/RS, cada um com suas particularidades, história e relevância cultural, potencialidades, usos e atividades, e suas fragilidades. 
Tal estudo teve um tempo extenso de aplicação dos duzentos e sessenta e um questionários necessários, bem como de outras etapas essenciais. Porém, foi além de uma simples coleta de dados, uma vez que se pôde dialogar com a comunidade de Panambi. Cidadãos esses que possuíam memórias, afinidades, repulsas e sonhos para com esses espaços livres. Menciona-se que não houve grandes dificuldades no decorrer do trabalho, mas, cita-se a inserção de todos os dados coletados nas planilhas eletrônicas, que demandou tempo e muita organização, devido à quantidade de perguntas e questionários. Salienta-se que praticamente todos os cidadãos que foram abordados concordaram em colaborar com o estudo.

Além disso, destaca-se que a subjetividade influência nos dados coletados. Ou seja, a mesma pesquisa, em uma estação diferente, em uma época/tempo diferente, com pessoas diferentes poderia ou não proceder em diferenciados conjuntos de dados e investimentos recomendados.

Logo, a respeito da "Pesquisa de Preferência da Paisagem" que foi aplicada através dos questionários, suas partes mais complexas (em que os cidadãos sentiram dificuldades para responder), foram aquelas questões descritivas (palavras-chave; aspectos positivos e negativos; sentimentos despertados; atividades que gostaria de fazer; qual ambiente gosta mais; aspectos que necessitam de investimento), que também exigiram de um tempo maior para algumas pessoas. Também, durante as entrevistas, descobriu-se a dificuldade das pessoas em reconhecerem os espaços livres pelo seu nome, o que levava a pesquisadora a indicar outros pontos de referências e características para reconhecerem a área.

Considera-se que o procedimento acima apontado facilitou no cumprimento nos objetivos estabelecidos, em virtude de agregar a valoração das fotografias (que representaram os ambientes existentes de cada espaço livre e as preferências neles), as particularidades de uso de cada entrevistado, e as suas considerações em relação à satisfação e qualidade das paisagens.

Em vista disso, acredita-se que o levantamento/diagnóstico das áreas formou uma composição mais urgente e relevante de recomendações, com o propósito de contribuir para a gestão das paisagens e condicioná-los em grande parte conforme as percepções e opiniões dos usuários.

Dentre essas recomendações para cada espaço livre, ressalta-se a valoração que foi indicada nas fotografias das praças e parque e que podem orientar na urgência e necessidade de manutenção ou revitalização. Pois, foram diversos os espaços físicos que receberam uma valoração nas fotografias média e baixa, e evidencia-se a satisfação dos respondentes quanto à qualidade das áreas e da gestão, que foi consideravelmente média e baixa nas quatro praças.

Além disso, como se observou nos resultados da Tabela 1, o Parque Municipal é a paisagem com maior valoração dentre as demais, em que os cidadãos reconhecem sua ampla área territorial, infraestrutura, recursos naturais (Rio Fiúza, APP, flora e fauna) e as diversas áreas e atividades possíveis. Porém, por esses 
mesmos motivos, constatam que são necessários investimentos em sua estrutura e mobiliário urbano, manutenção e limpeza constante em todas as áreas. Percebeu-se também que no parque podem-se explorar de forma minuciosa os esportes, recreação, o turismo, e educação para a conservação da paisagem, e acrescentar também as seguintes possibilidades de lazer e recreação: pista de ciclismo, área gourmet, e playground amplo.

Para a Praça Engo Walter Faulhaber, ponto central da evolução urbanística, ponto de referência e de ampla circulação para o município, também se verificou recomendações relevantes relacionadas à melhoria de sua infraestrutura física (principalmente direcionada aos sanitários), pavimentação, mobiliário urbano, paisagismo e em sua segurança. Ainda, salientou-se o seu potencial para explorar e aprofundar na divulgação da história local e municipal, no lazer e recreação para apreciação, e maior interação em espaços de convívio.

Nas Praças Hermann Steiger, da Emancipação e do Imigrante, mesmo com suas particularidades, a percepção dos questionados é de abandono desses espaços livres. Neste sentido, as recomendações foram semelhantes e urgentes quanto à necessidade de se investir no mobiliário urbano, manutenção/limpeza, infraestrutura, pavimentação e paisagismo. Notou-se que embora essas praças sejam de área territorial menor, e que contemplam poucas ou apenas uma opção de lazer e recreação, a amostragem de respondentes demonstrou que com uma manutenção eficaz e o acréscimo de mais atividades ou espaços de lazer e recreação pode-se vir a torná-las mais atrativas para a permanência e uso da população.

Com isto posto, acredita-se que o método de pesquisa de Preferência da Paisagem, com os questionários, foi de grande valia ao acrescentar à pesquisa de Pippi et al (2015), a valoração de fotografias, o nível de satisfação dos usuários em relação à gestão, e outras questões qualitativas. E, pensa-se que pode ser replicado em outros espaços livres, respeitando e acrescentando também outras questões particulares necessárias de cada área.

Portanto, percebeu-se a relevância do trabalho ao buscar compreender os recursos existentes e usos que são atribuídos às paisagens, e, contribuir com a gestão dos espaços livres, nos âmbitos de valorizar as potencialidades locais, investir nas fragilidades, possibilitar melhor apropriação e identidade e promover a conservação ambiental.

Todavia, mesmo ao saber que existem outras prioridades em relação á vida pública, e que o orçamento é limitado, aproveita-se a receptividade da gestão pública atual para reivindicar pelas recomendações e sugestões ponderadas nas áreas de recreação e lazer do bairro centro de Panambi, ao almejar que os espaços livres cumpram a sua função na cidade e mantenham equilíbrio no meio urbano, com conforto e qualidade de vida para os cidadãos. 


\section{AGRADECIMENTOS}

A autora agradece a Coordenação de Aperfeiçoamento de Pessoal de Nível Superior (CAPES) pelo apoio financeiro.

\section{REFERÊNCIAS}

ANDRÉ, Pierre; SCHWARZ, Maria L.; SEVEGNANI, Lucia. Preferências e valores para com as paisagens da Mata Atlântica: uma comparação segundo idade e o gênero. Revista Caminhos da Geografia, Uberlândia, v.9, n. 16, p. 114-132, jun. 2008. Disponível em: < http://www.seer.ufu.br/index.php/caminhosdegeografia/article/viewFile/15797/8930 >. Acesso em: 20 jan. 2017.

BERNÁLDEZ, Fernando G. Invitación a la ecologia humana: la adaptación afectiva al entorno. Madrid: Tecnos, 1985.

BIONDI, Daniela; KOZERA, Carina; VIEIRA, Carolina H. S. D. Preferência visual de paisagens do Parque Municipal do Passaúna, Curitiba, PR. Revista Paisagem Ambiente, n.24, p. 421-430, 2007. Disponível em: < http://www.revistas.usp.br/paam/article/view/86816/89815 >. Acesso em: 20 jan. 2017.

BOLÓS, Maria. Manual de ciencia del paisage: Teoría, métodos y aplicaciones. Barcelona: Masson S. A., 1992.

GIL, Antonio C. Métodos e técnicas de pesquisa social. 6 ed. São Paulo: Atlas, 2008.

KAPLAN, Rachel. The analysis of perception via preference: a strategy for studying how the environment is experienced. Lanscape Planning, Amsterdam, v. 12, p. 161-176, 1985. Disponível em:< https://deepblue.lib.umich.edu/bitstream/handle/2027.42/25604/0000151.pdf?1The >. Acesso em: 01 jul. 2017.

KARJALAINEN, Eeva. The visual preferences for forest regeneration and field afforestation: four case studies in Finland. 111f. Tese (Doutorado). University of Helsinki, Helsinki, 2006.

MACEDO, Silvio S. Espaços livres. Revista Paisagem e Ambiente, São Paulo, n. 7, p. 15-56, jun. 1995.

MACEDO, Silvio. S; ROBBA, Fábio. Praças brasileiras. São Paulo: Edusp, 2002.

MACEDO, Silvio S.; SAKATA, Francine G. Parques urbanos no Brasil. 3. ed. São Paulo: Edusp, 2010.

MACEDO, Silvio S. et al. Considerações preliminares sobre o sistema de espaços livres e a constituição da esfera pública no Brasil. In: ANDRADE, Rubens de; SCHLEE, Mônica B.; TÂNGARI, Vera R. (Org.). Sistema de espaços livres: o cotidiano, apropriação e ausências. Rio de Janeiro: Universidade Federal do Rio de Janeiro, Faculdade de Arquitetura e Urbanismo, Pós-Graduação em Arquitetura, 2009. p. $60-83$.

MAGNOLI, Miranda M. E. M. Espaços livres e urbanização: Uma introdução a aspectos da paisagem metropolitana. 1982. Tese (Livredocência) - Faculdade de Arquitetura e Urbanismo, Universidade de São Paulo, São Paulo, 1982.

MASCARÓ, Juan L. (Org.) Infra-estrutura da paisagem. Porto Alegre: Masquatro Editora, 2008.

PEREIRA, Frank G. O pampa como bioma e paisagem cultural: um estudo de percepção ambiental e preferência paisagística. 2012. 167f. Dissertação (Mestrado em Geografia) - Universidade Federal do Rio Grande, Rio Grande, 2012.

Plano Diretor Participativo de Desenvolvimento Municipal de Panambi - RS. 2008.

MARENZI, Rosemeri C. Estudo da valoração da paisagem e preferências paisagísticas no município de Penha - SC. 1996. $135 f$. Dissertação (Mestrado em Ciências Florestais), Universidade Federal do Paraná, Curitiba, 1996.

MARTINS, Larissa F. V. Monitoramento de parques urbanos em fundos de vale: análise das funções de conservação e uso público estudos de casos múltiplos em Curitiba, Paraná. 2014. 134f. Tese (Doutorado em Geografia Física) - Universidade de São Paulo, São Paulo, 2014.

Museu e Arquivo Histórico Professor Hermann Wegermann - MAHP. Panambi: De Colônia a Município. 2 ed. Panambi: Bühring Ltda., 2014.

PIPPI, Luis G. A. et al. A dinâmica dos espaços livres intra-urbanos da cidade de Santa Maria-RS. Revista Paisagem e Ambiente, São Paulo, n. 29, p. 189-226, 2011. Disponível em: < http://www.revistas.usp.br/paam/article/view/85315 >. Acesso em: 27 set. 2016.

PIPPI, Luis G. A. et al. Utilização de multimétodos de caracterização e análise da paisagem e dos espaços livres intraurbanos de Santa Maria - RS. Revista Paisagem e Ambiente, São Paulo, n. 36, p. 139-175, 2015. Disponível em: <

http://www.revistas.usp.br/paam/article/view/103858 >. Acesso em: 27 set. 2016. 
RODRIGUEZ, José M. M.; SILVA, Edson V. A. Planejamento e gestão ambiental: subsídios da geoecologia das paisagens e da teoria geossistêmica. Fortaleza: Edições UFC, 2013.

SANTIAGO, Alina G. As formas de uso no sistema de espaços livres: evento e cotidiano no espaço central de Florianópolis. In: ANDRADE, Rubens de; SCHLEE, Mônica B.; TÂNGARI, Vera R. (Org.). Sistema de espaços livres: o cotidiano, apropriação e ausências. Rio de Janeiro: Universidade Federal do Rio de Janeiro, Faculdade de Arquitetura e Urbanismo, Pós-Graduação em Arquitetura, 2009. P. 228-239.

TUAN, Y. F. Topofilia: Um estudo da percepção, atitudes e valores do meio ambiente. Tradução de Lívia de Oliveira. São Paulo: Difel, 1980. 


\section{ANEXO A - PESQUISA DE PREFERÊNCIA DA PAISAGEM}

\section{PROGRAMA DE PÓS-GRADUAÇÃO EM GEOGRAFIA - UFSM}

\section{ESPAÇO LIVRE:}

HORARIO/TEMPPO DE APLICAÇÃO:

DATA:

PERTODO DO DLA: MANHA - TARDE - NOITE

\section{DADOS PESSOAIS}

Gênero: ( 1 ) Feminino ( 2 ) Masculino
Idade:
(1) Até 17 anos
(2) De 18 a 44 anos
Escolaridade: (1) Fundamental
( 3 ) Superior incompleto
( 3 ) Mais de 45 anos
(2) Medio completo
( 5 ) Pós-graduação

\section{AVALIACAOO DAS FOTOGRAFIAS}

As fotografias deverão ser avaliadas dentro da Classe de Preferência de 1 a 5 .

\section{Classe 5 - Preferência Muito Alta Classe 2 - Preferência Baixa}

Classe 4-Preferência Alta Classe 1-Preferência Muito Baixa

Classe 3 - Preferêcia Média

\begin{tabular}{|c|c|c|c|c|c|}
\hline FOTO & CLASSE & FOTO & CLASSE & FOTO & CL.ASSE \\
\hline 1 & & 3 & & 5 & \\
\hline 2 & & 4 & & 6 & \\
\hline
\end{tabular}

Qual(is) as fotografias mais representativas do espaço livre? Porque?

\section{UTILIZA O ESPACO LIVRE PARA:(podes marcar mais que uma)}

\section{( ) Atividades fisicas}

( ) Caminhar/passear/brincar com animais

( ) Contato com a natureza

( ) Criatividade

( ) Estimulo

( ) Estar com a familia

( ) Fuga das pressões sociais/pessoais

( ) Interagir com vizinhos do bairro

( ) Introspecção/espiritualidade

( ) Observação da fauna

( ) Observar pessoas

( ) Proximidade de áreas comerciais

( ) Proximidade da minha residência

() Presença de academia ao ar live

( ) Circulação
( ) Apreciação
( Conhecimento
() Bons serviços/infraestrutura
( ) Curtição/prazer
( ) Interação social
( ) Eventos
() Meditar/relaxar
() Observar paisagem
() Programas educacionais
( ) Presença de playground/pracinha
() Piqueniques/ refeições
() Solitude
( ) Turismo

Fonte: QUAPÁ-SEL Núcleo Santa Maria - PARQ CAU - UFSM, modificado pela autora.

Com que frequência utiliza o espaço livre?
( ) Todos os dias
( ) $1-3 x$ por seman
( ) $1-3 \mathrm{x}$ por mês

( ) Mais de $3 \mathrm{x}$ ao mês ( ) $1 \mathrm{x}$ ao ano

Quando você geralmente utiliza o espaço livre?

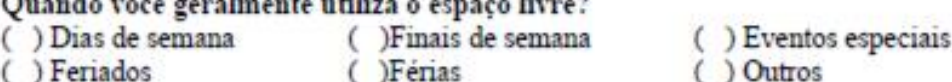
( ) Fias de sem
( )Férias

Qual horário você geralmente usa este espaço livre?
( ) $6-11 \mathrm{~h}$ (manhã)
( ) $12-16 \mathrm{~h}$ (tarde)
( ) $17-20 \mathrm{~h}$ (noite)

( ) Depois das $20 \mathrm{~h}$ (noite)

Quanto tempo você fica neste espaço livre?
$\begin{array}{lll}\text { () ) Menos de } 10 \mathrm{~min} & \text { ( ) } 10-30 \mathrm{~min} & \text { ( ) } 31 \mathrm{~min}-1 \mathrm{~h}\end{array}$

$\begin{array}{lll}\text { ( ) } 1-2 \mathrm{~h} & \text { ( ) } 2-3 \mathrm{~h} & \text { () Mais de } 3 \mathrm{~h}\end{array}$

Você utiliza este espaço público com:
( ) Sozinho
( ) Com amigo/s
( ) Com a familia
$\begin{array}{ll}\text { () Com crianças } & \text { () Com grupos religiosos () Com animais domésticos } \\ \text { () Com membros/clube } & \text { () Outros }\end{array}$

O quanto é importante você socializar com pessoas neste espaço livre:
( ) Não é importante
( ) Importante
( ) Muito importante

Qual o nívelgrau de satisfação quanto à qualidade do espaço livre:
( ) Baixo Médio
Qual o nivelgrau de satisfaçào quanto a gestào do espaço livre:
() Baixo

Defina este espaço livre ên três palavras:-

Aspectos positivos:

Aspectos negativos:

Que sentimentos o espaço livre desperta em ti?

Qual/quais atividades você gostaria de fazer neste local?

Quais os ambientes deste espaço livre que você gosta mais? Por quê? 